\title{
Competitiveness in the construction industry: A contractor's perspective on barriers to improving the construction industry performance
}

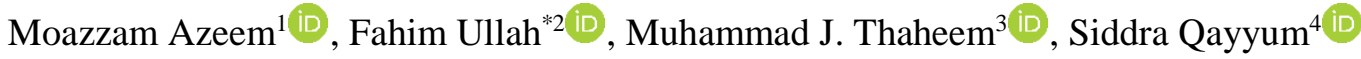 \\ ${ }^{1}$ National University of Sciences \& Technology, Department of Construction Engineering and \\ Management, Islamabad, Pakistan \\ ${ }^{2}$ University of New South Wales, School of Built Environment, Sydney, Australia \\ ${ }^{3}$ Deakin University, School of Architecture \& Built Environment, Geelong, Australia \\ ${ }^{4}$ University of New South Wales, School of Built Environment, Sydney, Australia
}

\begin{abstract}
Competitiveness is a complex domain with multiple perspectives and a vast range of definitions, meanings, and measures. Therefore, it is challenging to create an appropriate framework to evaluate the competitiveness of an ever-changing and evolving construction industry. This study captures the contractor's perspectives about the competitiveness of the Pakistani construction industry, underlines the key factors affecting its performance, and proposes a framework for enhancing competitiveness. The proposed framework identifies the areas for improvement and contributes to the development of strategies for adoption. To achieve this, a qualitative approach is adopted which captures the opinion of contractors about the competitiveness and its perception and analyzes it through the fuzzy approach. The results based on 25 expert interviews highlight that the recruitment of well-trained human resource and cutting-edge technologies, the collaboration between academia and industry, investment in R\&D projects, and a stable business environment contribute to enhancing the competitiveness of the construction industry and should be adopted to enhance the current state of practice. The study has perks for both academia and industry and requires active participation from both counterparts as well as supply chain actors and regulatory bodies to achieve the holistic goals.
\end{abstract}

\section{Keywords}

Competitiveness; Construction industry; Contractor perspective; Construction performance; Competitiveness barriers

Received: 04 July 2020; Accepted: 21 September 2019

ISSN: 2630-5771 (online) @ 2020 Golden Light Publishing All rights reserved.

\section{Introduction}

Competitiveness is a concept regularly debated by industrialists, politicians, economists, journalists, and academics. The US Commission on Industrial Competitiveness described it as "the ability of a country to produce goods and services that meet the test of international markets and simultaneously maintain and expand the real income" [1]. Competitiveness has several inclusive definitions, meanings, and measures. But this vastness brings ambiguity despite the widespread recognition of its significance [2]. Several steps are taken to highlight

\footnotetext{
Corresponding author

Email: f.ullah@unsw.edu.au
} 
and explain the domains for assessing construction competitiveness through the establishment of councils, and the release of white papers or reports on construction competitiveness [3]. For instance, the European Union, the US, and other governments set up competitiveness councils. The World Economic Forum (WEF) and the International Institute of Management Development (IMD) annually produce the global competitive report, sizing a nation's competitiveness index [1]. However, the works are far beyond the requirements of the modern globalized world and the associated construction industry requirements. As such a holistic framework and evaluation model for competitiveness assessment at both global and regional levels is missing $[2,4]$. To reach a global consensus, it is imperative to assess the competitiveness and subsequently develop a competitiveness index for country-specific construction organizations. Similarly, for the regional assessments, it is imperative to assess the system of infrastructure links that connect the specific assets of independent companies forming the cluster [5]. Among the proposed solutions, implementation of the provisions of international standard ISO 9000 series as an effective solution to the problem is indicated by Safonova and Tatarnikova [6].

The construction industry plays a vital role in the economy; it is a key to achieving socioeconomic growth such as providing shelter, infrastructure, and employment. It also contributes to elevating and developing the business of supporting industries. If the construction sector operates at full capacity, it creates job opportunities since it rigorously involves labor. Thus it engages large sections of a nation's unskilled and skilled workforce and related industries. In the case of Pakistan, the construction and housing industry are providing business and services to over 60 industries [7-9]. Therefore, the progress of the construction business directly affects other industries and the overall economy, leading to national development. According to Fox and Skitmore [10] and Low, Abdul-Rahman [11], some of the factors influencing the development of the construction industry are: long-term vision and policy, basic physical and institutional infrastructure, thinking and implementing the best (a best practice and learning culture), financial and human resources, and, techniques assisting high production performance. Similarly, aspects such as time and cost overruns [12, 13], quality and associated management of constructed facilities using innovative tools such as six sigma [14], management of larger infrastructure projects such as public-private partnership based endeavors [15], and labor productivity and associated assessments [16-18] are some other issues faced by the global construction industry.

The topic of engaging the industry in the development and implementation of an integrated strategy for sustained and innovation-based competitiveness has been studied globally [19]. Also, the competitiveness has been explored in Pakistan from various angles in different industries such as trade industry [20], common facility centers and their influence on small and medium enterprises [21], agricultural exports [22], rice exports [23], healthcare systems [24] and technological acquisitions [25]. However, no such study exists for the construction industry and it has yet to benefit from the wider understanding of academia on this topic. Competitiveness is a complex domain and many academics and policymakers use the concept without fully considering what it means and how it can be measured [26]. Therefore, it is challenging to create an inclusive framework for its evaluation that covers multiple perspectives. This provides an impetus for the current study which proposes a model to assess the competitiveness of the construction industry, identifies opportunities for improvement and contributes to the development of strategies for its adoption in the context of developing countries. Accordingly, the basics of competetivess in local context is investigated in the current study. Basing its roots in the key factors identified from the literature that are vetted by local practitioners for a localized context, key parameters of competitiveness have been assessed in the 
Pakistani construction industry. Such a study has not been conducted before in the local context which makes it a unique attempt to assess the competitiveness of Pakistani construction industry. Special attention has been given to construction specific aspects at both the government and firm levels to propose a holistic frameowork for promoting competitiveness in the construction industry.

The construction industry of Pakistan has experienced many ups and downs over the past few decades with many problems and challenges confronting it. These include poor site safety record, unsatisfactory environmental performance, vast use of traditional and labor-intensive construction methods, incompetent workforce, short-term attitude to business development, and, fragmentation and adversarial culture within the industry [18, 27-29]. Sheikh, Ullah [16] emphasize labor productivity and associated poor workmanship as one of the key barriers to the progress of the local construction industry. Ullah, Thaheem [30] indicate a lack of innovation and innovative techniques such as lean construction and six sigma as key issues related to aggravating quality concerns among stakeholders. Hasnain, Thaheem [31] underline procurement issues such as personal preferences for contractor selection instead of the one offering the best value leading to project failure. Kamal, Zahoor [32] highlight the mismanagement of construction risks as another critical factor in the underperformance of the local construction industry. And Arshad, Qasim [33] reveal the vast amounts of physical waste generated on the construction sites overloading the economic and environmental performance of the industry. Similarly, other issues include time and cost overruns [12, 34], risk management and quality concerns of large scale projects such as publicprivate partnerships [7, 30, 35, 36], lack of adopting innovative assessment and visualization tools such as BIM [37, 38], and the lack of collaboration and the increasing gap between industry and academia [39].

Owing to these issues, the current study proposes a model to address these problems and provides competitiveness guidelines for the practitioners. Based on several studies that proposed different parameters or variables to evaluate competitiveness at diverse levels [40-42], a framework for assessing competitiveness is modeled in the context of Pakistan's construction industry. The framework consists of 7 parameters: construction industry environment, competitiveness at the firm level, potential, supporting factors, flexibility, construction business environment, and economics and finance that are adopted mainly from the comprehensive literature review and in-depth discussion with 10 practitioners having at least 10 years of industrial experience as shown and explained in Table 1.

Each competitiveness parameter includes several associated factors. The findings of this study expand the body of knowledge on sustainability assessment related to competitiveness and enhancement in the context of developing countries, such as Pakistan

\section{Literature review}

Competitiveness has become a prominent term throughout the last three decades and its meaning, scope, depth, and importance have been discussed in various disciplines, such as economics, management, and political science [43]. It is now accepted as an idea that is better than conventional economic drivers such as profitability, productivity, or market share which lack the potential to facilitate the consistent improvement of performance [17, 41]. In the construction sector, competitiveness has recently gained momentum [42]. According to Cao, Li [40], structural characteristics of the projectbased interfirm collaboration networks that embed the design and construction organizations are related to their long-term organizational competitiveness. Further, organizational experience in participating in large and influential projects, ownership type and the age of an organization, and an organization's size in relationship networks in an earlier period predict the organizational success in winning new contracts, later on, thereby enhancing its competitiveness [2]. 
Table 1. Parameters of competitiveness assessment, their explanation and subfactors

\begin{tabular}{lll}
\hline Parameters & Explanations & $\begin{array}{l}\text { Sub factors highlighted from literature } \\
\text { and discussion with practitioners }\end{array}$ \\
\hline $\begin{array}{l}\text { Construction } \\
\text { industry } \\
\text { environment }\end{array}$ & $\begin{array}{l}\text { This refers to the overall behavior } \\
\text { of the construction industry and } \\
\text { the environment for } \\
\text { competitiveness in local contexts. }\end{array}$ & $\begin{array}{l}\text { Strategic behavior, Lack of adequate } \\
\text { anti-monopoly policy, Containment of } \\
\text { restrictive practices, Competitive } \\
\text { relations, Focus on sustainability and } \\
\text { innovation, Health and safety concerns, } \\
\text { stances on the environment. }\end{array}$ \\
$\begin{array}{l}\text { Competitiveness } \\
\text { at the firm level }\end{array}$ & $\begin{array}{l}\text { This refers to the will of firms to } \\
\text { be competitive in the industry. }\end{array}$ & $\begin{array}{l}\text { Needs and expectations of companies, } \\
\text { clients, and society, the probability of } \\
\text { export, knowledge management, } \\
\text { innovation capabilities, motivations, } \\
\text { Research and Development (R\&D), } \\
\text { Strategic Planning and Management, } \\
\text { Resources acquisition and management, } \\
\text { Sustainability awareness, and waste } \\
\text { management, data archiving. }\end{array}$
\end{tabular}

Potential of the This refers to the capabilities and Firms

Competitiveness supporting factors

Firm flexibility

\section{Construction} business environment

Economics and Finance potentials of the firms to be competitive in the industry.

This refers to the initiatives and support provided by the relevant authorities and governments to the firms to enhance competitiveness.

This refers to the flexibility in approaches related to operations, tactics, strategies, managerial willingness to listen to alternate options, and the adoption of new tools and techniques.

This refers to the environment for conducting construction business as established in the local practices and the culture of the local industry. and finances available to uplift
Capabilities of businesses, labor productivity, production capabilities, Resource sustaining potential, efficient organization of construction operations, up-to-date production, and labor technology, technology adoption capabilities, digitalization potential.

Initiatives and incentives by the government, government policies, legal frameworks, Industry-Academia collaboration, Performance and proficiency of subcontractors, Innovation Capabilities, fair play, and best value selection.

Operational flexibility, tactical flexibility, strategic flexibility, managerial flexibility, contractual flexibility, stakeholders' flexibility, new tools adoption flexibility, Health and Safety Initiatives, Quality Management approaches.

Collaborative working, Partnering and Alliancing, Organizational Culture, Communication, Coordination and Cooperation, Munificence, Dynamism, Competitive intensity.

Economic capabilities of the local contractors, government funding, circular economy, purchase power, investment capabilities, public and private funding initiatives. state of the industry including industrial support initiatives and general economic standings of the
References

[94-96]

$[1,97,98]$

$[56,58,99$, 100]

$[38,39,101$, 102]

$[56,103,104]$

$[94,95,105$, 106]

[62, 107-109] local industries.

Orozco, Serpell [44] argue that leadership has the strongest impact on the competitiveness of construction organizations followed by contract management and health and safety management. 
Similarly, according to Toppinen, Sauru [42], internal and external factors affecting the future competitiveness of the construction industry include the presence of skilled architects and builders, standardized building codes and systems, development of technical infrastructure and project-based business networks, and the presence of regulatory frameworks.

The concept of competitiveness has been broadly utilized especially in connection with national competitiveness [45]. Additionally, competitiveness at a firm or industry level has also been investigated through different perspectives. Malmberg and Maskell [46] explored it in the context of the economy and the performance of firms and industries in relation to space and place. Chang, Zuo [47] explored it in the context of product-service development and sustainability and argued that these traits are interrelated and directly proportional such that uplifting one improves the state of the other. Camagni [48] explored it in the context of territorial capitals and argues that localized capitals and distributions of finance to the bottom or grassroots level empowers the local and regional industries, increasing the competitiveness at the regional level and improving the overall competitiveness. Similarly, Aldy and Pizer [49] report that competitiveness is impacted by climate change mitigation policies and the two can support each other where a focus on one can enhance the other and vice versa. Further, competitiveness can also be affected by the stress levels across different genders as emphasized by Cahlikova, Cingl [50] where people of different genders behaved and performed differently when in control vis-à-vis subject positions that affected the willingness to compete. Similarly, while exploring the brand based competitiveness for hotels in Hong Kong, $\mathrm{Xia}, \mathrm{Vu}$ [51] argue that having a more recognized and global brand helps attract more customers and increase the state of competitiveness. Thus, competitiveness is defined as a feature set that makes a brand more distinct.

Competitiveness research at the industry level is comparatively scarce as compared to the firm or project level [40, 52]. Orlov and Chubarkina [53] explored it in the context of social infrastructure development for smart cities and argue that effective implementation of construction projects suggests creating value innovation through the transformation of the so-called strategic canvas for social infrastructure facilities. Similarly, the concepts of technological innovation, adoption, and associated implementation have been linked to the success and competitiveness of modern age smart real estate [19, 54-58]. Likewise, Chang, Zuo [47] argued that the social, economic, and environmental aspects of sustainability, if incorporated in the construction along with the attitude towards innovation and sustainability adoption, can enhance the competitiveness and performance of the construction industry. Pan [59] has linked construction competitiveness to its productivity and argues that firm and project-level productivity are affected by incomplete documentation, design changes, inefficient project management, and supply chain fragmentation, contributing to the deteriorating state of the construction industry and its competitiveness.

There are various definitions to support the concept of competitiveness in different perspectives. Flanagan, Ericsson [60] debated that competitiveness is a modifiable term and can be used in various contexts with different characteristics such as: (1) it is multi-characterized; there is no general definition of competitiveness, (2) it is multi-measured; there are different methods of measuring competitiveness that change to its distinctive definitions, (3) it is multi-layered; a concept applicable at the national, industrial and firm levels, (4) it is dependent; its significance relies upon the actors and stakeholders under consideration, and (5) it is dynamic; its determinants change with time and context.

Competitiveness is the ability of the construction industry to fulfill the complex demands of its clients under the effects of the global market environment [1, 61]. At this level, competitiveness research has seen a thorough debate between productivity and competitiveness. Pan, Chen [62] described competitiveness as a modern word and utilize productivity to explain 
competitiveness without distinguishing the difference between the two concepts. However, Flanagan, Ericsson [60] debated that competitiveness measures established only on productivity in the construction sector do not sufficiently cater to the effect of technological change and factor substitution. Therefore, there is a need to consider more dimensions. Furthermore, the multifaceted competition is increasing the overall complexity of decision-making. Organizations have a variety of control variables such as price and monetary gains, process, and product innovation, quality, and reliability of products and services, speed and precision of delivery, etc. Roughly, the construction companies can utilize the price reduction and quality and safety maintenance formula to remain competitive. In the construction sector, competitiveness can be analyzed on four different levels including nation, industry, organization and project.

National competitiveness can be explained as "a country's ability to create, produce, distribute, and/or service products in international trade while earning rising returns on its resources" [63, 64]. Industrial competitiveness can be explained as the ability of an industry to meet challenges posed by foreign competitors $[3,46,65,66]$. Organizational competitiveness can be defined as "the ability of an organization to carry its core competencies, as well as capabilities that drive such competences, form the essence of competitiveness. This includes enhancing the customer and shareholder values, focusing sustainability, analyzing competitiveness mapping, and focusing performance measures for increasing competitiveness" [61, 67, 68]. Similarly, firm competitiveness can be defined as "the degree to which a firm can produce goods and services that meet the test of international markets while simultaneously maintaining or expanding the real incomes of its employees and owners" $[69,70]$.

As much as it is important in laying a foundation for a long-term and sustainable construction industry, it is challenging to measure the overall industrial competitiveness [42]. However, competitiveness is important, and it affects future sustainable performance. Therefore, research in exploring analytical methods must be conducted. A complete competitiveness study must identify the most important factors and the relations between them [68]. In this context, five competitive forces model [71] that influences the profitability of an industry and the most applied and debated framework - the diamond framework of Porter [72], is most widely adopted and utilized. Thus, the current study proposes a competitiveness assessment framework for the Pakistani construction industry though the opinion and perspective of the contractors.

\section{Research methodology}

This study measures the competitiveness of the construction industry from the contractors' perspective. Due to a lack of studies on this subject and the exploratory nature of the study, a qualitative research design approach including semi-structured interviews is employed to obtain the perception of respondents towards various factors of competitiveness of the industry. For a complete competitiveness analysis, meaning and evaluation of competitiveness, the crucial factors affecting it, the relationship between these factors, and their influence on the competitiveness of the subject under examination must be defined [73, 74]. There is no single methodology to examining construction competitiveness, but keeping in mind the resource constraints, and the motivation, scope, and goals of the study, parameters attributed to Flanagan, Ericsson [60] are considered while selecting the approach. These attributes are a focus on reason or conclusion, opinions of the key stakeholders, the time aspect, space aspect to restrict it to national or global domains, and level of the study such as project, firm, or industry [75]. Based on these factors, this study captures the perspective of contractors about the present competitiveness of the domestic construction industry. The overall flow of this study is shown in Fig. 1. 


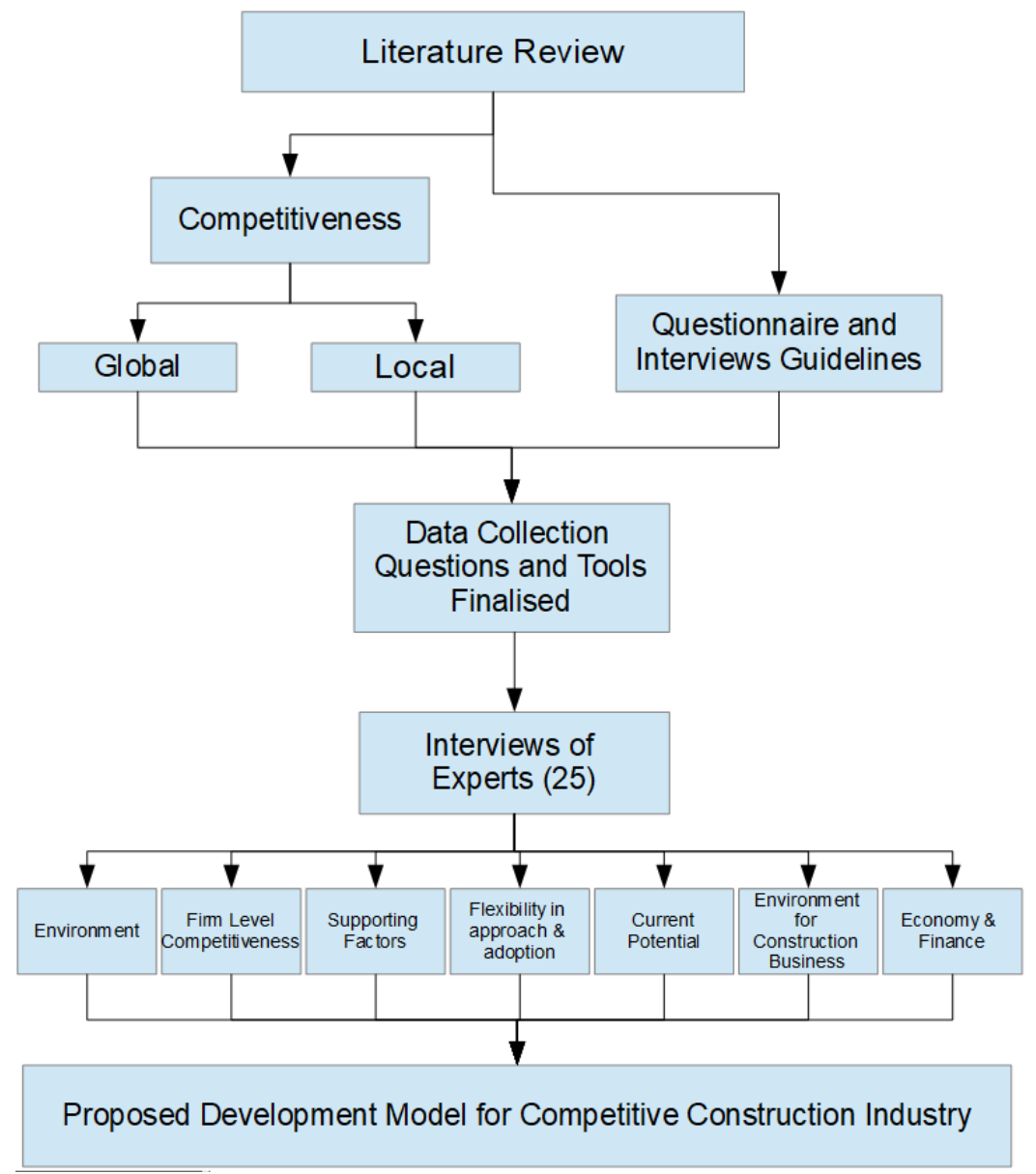

Fig. 1. Methodology of the study

Initially, a comprehensive literature review is conducted to explore the literature on competitiveness on global as well as local (Pakistan) level. Further, literature is reviewed to understand the developments and sample size associated with qualitative studies. A total of 156 systematically shortlisted articles were reviewed to highlight and group the seven key parameters of competitiveness assessments. Details of the shortlisted articles and mechanisms are provided in Table 2. Te related articles are sourced through the Scopus library. The search items comprised of "construction competitiveness assessment", "construction competitiveness framework" and "construction competitiveness in Pakistan". The search was restricted to research articles published between 2010-2020. From these articles more than 40 key factors were identified that contribute to competitiveness at global scales. These were discussed with 10 industrial practitioners working with contractors in Pakistan and having more than 10 years of experience to help minimize and group the factors for localized context as a preliminary study. Five of the practitioners were the CEOs or General Managers and the remaining five were working as Project Managers (3) and Construction Managers (2). Accordingly as previously shown in Table 1, seven parameters (groups) were finalized for inclusion in the current study. The keyword analysis was performed on the shortlisted articles using VosViewer® to highlight the top appearing keywords in the shortlisted articles. For this purpose, a minimum of appearance in 10 articles was kept as the shortlisting criterion. Accordingly out of the 3501 keywords, 38 met the criteria as shown in Fig. 2. 
Table 2. Search strings used on Scopus

\begin{tabular}{llcc}
\hline Search Engine & Search Strings & Results \\
\hline Scopus & ( TITLE-ABS-KEY ( construction AND competitiveness AND assessment ) & OR & 413 \\
& TITLE-ABS-KEY ( construction AND competitiveness AND framework ) & OR \\
& TITLE-ABS-KEY ( construction AND competitiveness AND in AND Pakistan ) ) \\
& PUBYEAR AFT 2010 AND LANGUAGE (English) & 278 \\
& DOCTYPE Limit & & 198 \\
& Duplicates & Final Shortlist & 156 \\
& &
\end{tabular}

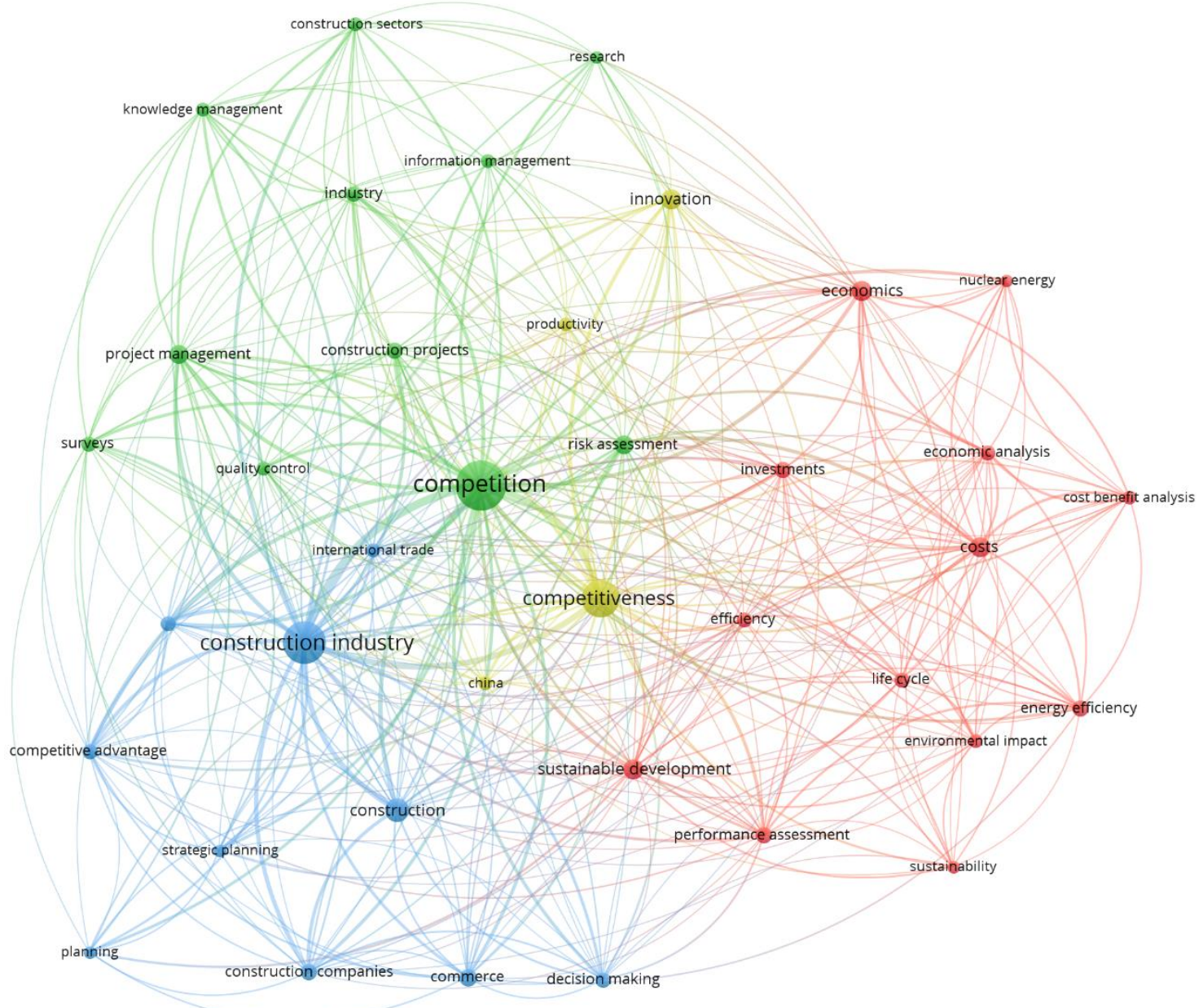

Fig. 2. Most repeated keywords in the reviewed literature

The top 10 keywords with the highest appearance were competition (143), construction industry (104), competitiveness (81), construction (34), project management (21), economics (23), sustainable development (23), construction companies (16), competitive advantage (15) and contractor (15).

In the next step, the data collection questions and tools are finalized where the interview is shortlisted as the most suited method for the current study, and the pertinent questions from similar 
studies are investigated to develop questions for interviews. Then, semi-structured interviews of 25 field experts working in the contracting organizations with at least 10 years of experience are conducted to capture their point of view on the seven shortlisted criteria for assessing the competitiveness of the Pakistani construction industry. Overall the interviews inquired about the state of construction competitiveness based on seven aspects that include the environment of the construction industry, competitiveness at the firm level, the supporting factors, flexibility in approach and adoption of new tools and techniques, estimation of the current potential, the environment for conducting construction business and the state of economy and finances available to uplift the state of the industry. Finally, based on the interviews, reviewed literature, local guidelines, and practices, a development model is proposed for uplifting the state of the Pakistani construction industry and making it more competitive.

For the selection of the sample size, the study by Baker, Edwards [76] was followed to achieve a sample size of roughly thirty (30) interviews. Similarly, Boddy [77] mentions that for most of the qualitative studies that involve experienced respondents and experts, a sample of 20 to 30 is typical and generally accepted. Further, Fugard and Potts [78] suggest a sample of 30 to 40 experts for qualitative studies. Accordingly, following Porter [72] methodology, which is also adopted by Öz [79] and Flanagan, Ericsson [60], the findings of this study are based on semi-structured interviews of 25 experts with an average of 18 years of experience. The interviewees occupied upper managerial and decision-making positions such as Directors, Project Managers, Senior Engineers, and Senior Managers in their respective firms. The interview questions were compiled to get descriptive answers. Since it is paramount to assess the uncertainties while dealing with competitiveness, the fuzzy analysis was considered. The fuzzy theory has a widespread application for assisting in decisionmaking under uncertainty [80]. In addition to the generic interview questions, the respondents were requested to rate the competitiveness factors based on their company's performance to highlight the state of decision-making, which can be assessed through fuzzy analysis.

For assessing the validity and reliability of results, a minimum threshold of 0.4 as reported by Maqsoom, Rehman [81] was used and all the values of questionnaire responses have been subjected to this value. Accordingly, all the values of Cronbach's alpha to assess the internal consistency reliability are found to be above 0.7 . Also, the average variance extracted is above 0.5 , which is a minimum threshold [82]. This indicates that the content of the questionnaire was sufficient to explain the considered parameters.

\section{Results and Discussions}

The interviews revealed the competitiveness of the Pakistani construction industry in terms of current practices. Accordingly, the differences observed in the opinion about the importance of factors pertinent to the framework of the competitiveness model are discussed. Under the method, seven aspects are explored pertinent to the competitiveness of the construction industry of Pakistan. In the first part of the interview, basic demographic details of the interviewees were recorded, as shown in Table 3.

Among the interviewed people, the ratio of male to female was very low with only $8 \%$ representation of the female respondents. This is pertinent to the fact that the number of females working in Pakistani industries especially that of construction and more specifically the contractor firms is very low. When inquired from the respondents about this, most of them responded that construction in Pakistan is considered more male-oriented due to the nature of the job as it requires working away from home and in far-flung areas raising safety concerns for females who are either reluctant to put themselves in such situation or are pressurized by their families against opting for such jobs.However, things are changing since recently and due to the many steps taken for women empowerment and gender mixing in the construction, more females are making their way into the industry and the ratio will improve in the future. 
Table 3. Demographics of the respondents and details of their organizations

\begin{tabular}{|c|c|c|c|}
\hline \multicolumn{2}{|c|}{ The Demographics Characteristics } & \multirow{2}{*}{$\begin{array}{l}\text { Frequency } \\
23\end{array}$} & \multirow{2}{*}{$\begin{array}{l}\text { Percentage } \\
92\end{array}$} \\
\hline \multirow{3}{*}{ Gender } & Male & & \\
\hline & Female & 02 & 08 \\
\hline & Unspecified & - & - \\
\hline \multirow{4}{*}{ Respondents' Age } & $20-30$ & 02 & 08 \\
\hline & $31-40$ & 08 & 32 \\
\hline & $41-50$ & 10 & 40 \\
\hline & 50 and above & 05 & 20 \\
\hline \multirow{5}{*}{ Experience } & $1-5$ years & - & - \\
\hline & $6-10$ & 02 & 08 \\
\hline & $11-15$ & 04 & 16 \\
\hline & $15-20$ & 14 & 56 \\
\hline & 21 and above & 05 & 20 \\
\hline \multirow{5}{*}{ Job/Role } & Director or CEO & 06 & 24 \\
\hline & Project Manager & 10 & 40 \\
\hline & Administration and Human Resources & 01 & 04 \\
\hline & Senior Engineers & 07 & 28 \\
\hline & Marketing and Sales & 01 & 04 \\
\hline \multirow{6}{*}{ Company's Age } & $1-10$ & - & \\
\hline & $11-20$ & 03 & 12 \\
\hline & $21-30$ & 05 & 20 \\
\hline & $31-40$ & 08 & 32 \\
\hline & $41-50$ & 05 & 20 \\
\hline & 50 and above & 04 & 16 \\
\hline \multirow{4}{*}{ Location } & Islamabad/Federal Region & 07 & 28 \\
\hline & Lahore/ Punjab & 08 & 32 \\
\hline & Peshawar/KPK & 04 & 16 \\
\hline & Karachi/Sindh & 06 & 24 \\
\hline
\end{tabular}

In terms of the age of the respondents, the median age was around 42 years which is consistent with the promotional requirements in the Pakistani construction industry where people start to acquire managerial positions mostly after their late 30's. However, due to the innovative endeavors by young entrepreneurs, some younger people were also found to occupy leadership positions and were interviewed. Further, the average experience of the respondents was 18 years with around $75 \%$ of the respondents having an experience of 15 years and above. Furthermore, in terms of their professional roles, more than half of the respondents were working as Project Managers and Senior Engineers in their respective organizations. Similarly, in terms of the age of the firms, around $68 \%$ were at least 30 years old, thus well established in the local market. Lastly, in terms of the holistic representation of the 
country, respondents geographically located throughout Pakistan were involved. These were mainly from the provincial capitals. Once the demographical data was collected, interview questions were asked in line with the seven shortlisted aspects.

\subsection{Environment of the local construction industry}

\subsubsection{Current situation of the Pakistani construction industry}

The majority of the respondents firmly believe that the current situation of the Pakistani construction industry is appalling. What makes the situation worse is that the industry is complacent of its low progress, and rarely reflects on its functioning and investigates the opportunities for advancement. There are many reasons associated with this behavior. According to a respondent "flourishing rate of our construction industry is a very subjective statement and cannot be answered in black or white, rather there are a lot of grey areas and the improvements depend on many factors, like government policies, dollar [exchange rate] fluctuation, etc.”. There are abrupt and unplanned cycles of progress as sometimes there is a boom in the economy, followed by an unforeseen recession. For example, some promising developments occurred such as the $6.5 \%$ observed growth rate compared to a mere $2.5 \%$ target in the fiscal year 2012, but in 2019 as opposed to the 2018 statistics, a serious downfall is observed [83]. Further, technological interventions are witnessed but due to their haphazard and unplanned nature, the overall technological competitiveness is much lower than several comparable regional counterparts like UAE, Saudi Arabia, China, and India. Further, the government policies and a lack of resolve regarding the tax and financial matters hinder the success process when it comes to the local construction industry. As one respondent explains, "it is difficult to run a project in Pakistan as compared to the Middle East". Though the government policies may support the industry if followed in a legitimate spirit, it is easier said than done due to the lack of holistic models and frameworks to distinguish the lawful from the unlawful. Further, there also exists an opinion that the internal policies developed by most of the government organizations are neither supportive nor realistic. For example, labor laws and the workman compensation policies used to date are the same as created or adopted at the time of Pakistan's creation (in 1947). Since then no meaningful reforms are made. This points to the lack of holistic, adaptive, and inclusive frameworks to support the construction business. According to most of the respondents, the situation is messy and needs proper scrutiny if the industry is to benefit from the perks of globalization and modern techniques. One of the responses in this context referred to the situation as the law of the jungle where there is no check and balance and the one with might may have the right.

\subsubsection{Health and safety situation}

On the issue of the government's stance on health and safety and environment (H\&S), its monitoring and implementing agencies, frustrated and disappointed responses were received. This is due to the lack of a construction regulatory body to monitor H\&S on construction sites in Pakistan such as the OSHA in the United States or Safe Works in Australia. Although the Pakistan Engineering Council (PEC) has started to work on this issue and arranged meetings and awareness seminars at university and local levels, the practical steps are yet to be taken. In this regard, construction health and safety legislation was launched in 2017 under the auspices of the Ministry of Planning Commission (Ministry of Planning Development \& Reform) but the bill was never tabled in the parliament for discussion, ratification, and implementation. Due to this lack of legislation and implementation, no punitive actions are taken in case of accidents and the industry, as a result, struggles to comply with the globally accepted safety standards. However, on the positive side, individual organizations have started to talk about construction $H \& S$ and there has been a growing interest in the industry's participation in various safety training and certifications organized by educational institutions. 


\subsubsection{Stance on the environment}

Just like the other developing countries, Pakistan is also facing environmental problems owing to its demographic growth, lack of public awareness and education, catastrophic mismanagement of water and other natural resources, natural disasters, and ill-planned urban and industrial expansion [83, 84]. Divided opinions are received about this aspect, with some suggesting that the environmental screening is carried out to the extent of documentation only and is usually limited to the time for which a consultant is hired. Once the consultant is out of the picture, no one bothers keeping the record updated. Thus, the proper implementation is never reported, and corrupt or incompetent practices help in getting desired results. Although consultants do a fairly good job of preparing the reports, the problem is that the reach and understanding of the environmental issues and regulations are not known to the local communities mostly because of a lack of awareness. As a result, it is easy to get away with environmental misconduct. Further, for improving the environmental conditions, there is little awareness and focus on environment-friendly solutions in the local construction industry. Currently, the level of effort in this area is not up to the mark; there is no dearth of theoretical knowledge at the upper managerial levels in the public and private organizations, but there is a general reluctance to implement such knowledge due to unappreciated short-term benefits and higher initial investment.

\subsection{Competitiveness at Firm level}

\subsubsection{Focus on research and development (R\&D)}

The private sector is increasingly participating in the construction industry and becoming a major part of the construction business in Pakistan. However, the majority of the firms are not involved in R\&D since they do not consider it as a tool for attaining a competitive edge and there is no incentive in the form of a tax rebate or innovation ratings to motivate them. The only investments in this aspect were observed in data collection activities for estimation and costing which is a partial application of R\&D and does not offer a full advantage to uplift the current state of the industry to become innovative or up to date. According to a Pakistan Council for Science and Technology (PCST) Survey 2009-10, the average investment in the $\mathrm{R} \& \mathrm{D}$ projects in the past two decades has been a mere $0.22 \%$ of GDP (with a standard deviation of 0.12). This is associated with a lack of awareness, motivation, or incentives by the government to private organizations that prevent spending on R\&D.

\subsubsection{Strategic planning and management}

It appears that the Pakistani construction companies pay less attention to and put less effort into strategic planning and management due to lack of awareness and the absence of tools for assessing and taking effective strategic measures. As shown in Fig. 3, there is no fixed strategy or measure adopted by the local organizations, instead a mixed approach is adopted which is a combination of certain techniques. This highlights the noninstitutionalization and complications of conducting construction business. Among the few underscored techniques and tools used for strategic planning, strengths, weaknesses, opportunities, and threats (SWOT) analysis is prominent with more than half of the respondents using it. However, as much as $40 \%$ of the respondents indicate not using any specific tool or techniques for such planning, hindering improvements in competitiveness and the state of innovation. The possible reason is the reactive approach in strategic as well as operational planning: in the face of increased competition, the top management of the local firms is faced with survival crises forcing them to focus on the emergent problems instead of holistic strategic planning and management. This poses multiple implications including the lack of understanding of the concept of strategic planning in the local industry and the fact that survival is such a huge challenge that it keeps the firms busy instead of thinking ahead and moving towards more innovation. 


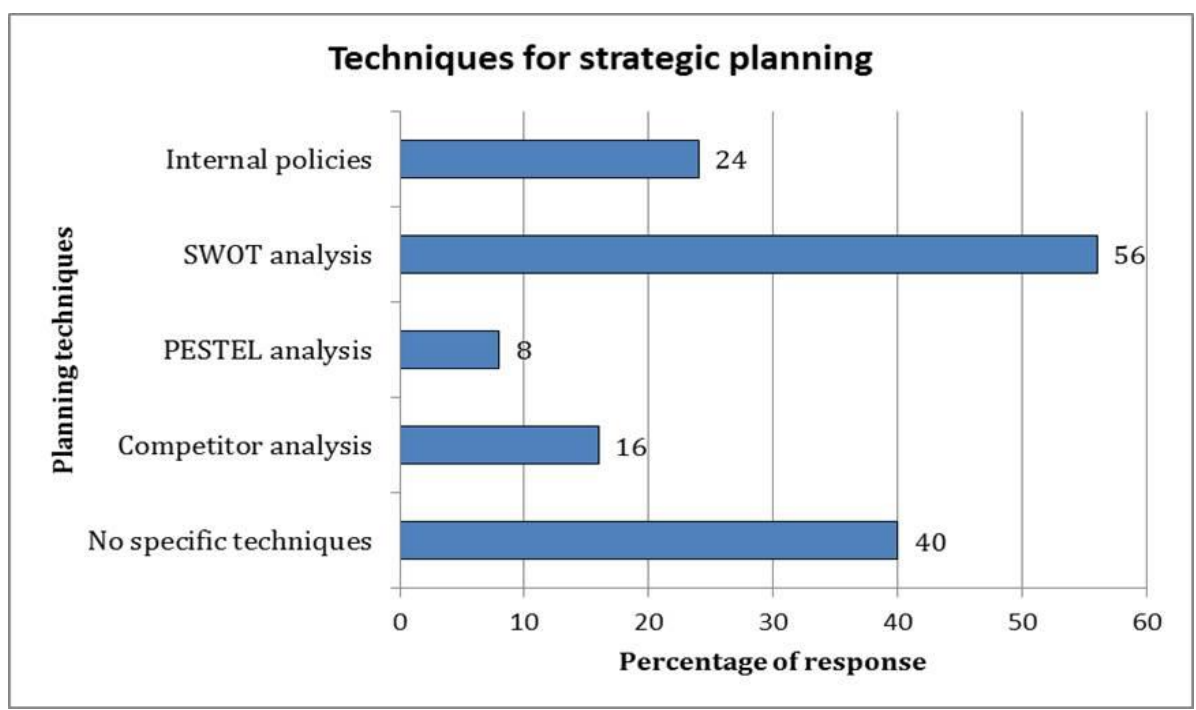

Fig. 3. Techniques for strategic planning adopted by the firms

\subsubsection{Resources acquisition and management}

Another key aspect of the lack of competitiveness at the firm level is that of human resources and construction machinery including issues such as inadequate awareness, recruitment of cutting-edge technologies, and excessive workforces comprising substantially of unskilled workers with hardly any appropriate technical training. However, this is partially addressed by the PEC conditions for registration or upgrading of firms which make it necessary for all construction firms to have a fixed number of qualified engineers on their payroll. For the current study, Fig. 4 lists the number of engineers employed by the interviewed organizations.

According to Maqsoom and Charoenngam [27], young Pakistani firms consider the experienced and qualified workforce more important than mature firms. Thus, these results are in line with the known trends as most of the studied organizations have less than $10 \%$ of engineers with a postgraduate degree. In total, 21 out of the 25 interviewed organizations have less than $20 \%$ of postgraduate engineers which is concerning. However, this cannot be put entirely on the organizations as other local factors also affect this since most of the postgraduate engineers in Pakistan tend to go for higher studies and shift to academia instead of working in the local construction industry. This is mainly due to a lack of growth for highly educated in the construction industry and a high potential of growth in the field which is more pronounced in academia than the industry in Pakistan. However as mentioned by Ullah and Thaheem [39], both these counterparts must bridge their gaps and work together to achieve holistic development and achieve innovation in construction.

\subsubsection{Sustainability awareness and waste management}

In terms of the awareness of sustainability in local firms, it is encouraging to see that awareness is increasing in the majority of the interviewed organizations. Techniques such as on-site operations optimization and the use of construction materials and techniques acquired through in-house project management units are reported by the interviewees. These units track, monitor, and implement the necessary measures such as efficient site management to reduce material waste, careful site planning to reduce unnecessary hauling of materials, and regular maintenance of plants and equipment for sustainable use of energy. Further, material management is performed to reduce waste on-site. However, the use of recycled or renewable materials or the recycling of site wastes is hardly practiced, leading to the disposal of large quantities of physical waste. 


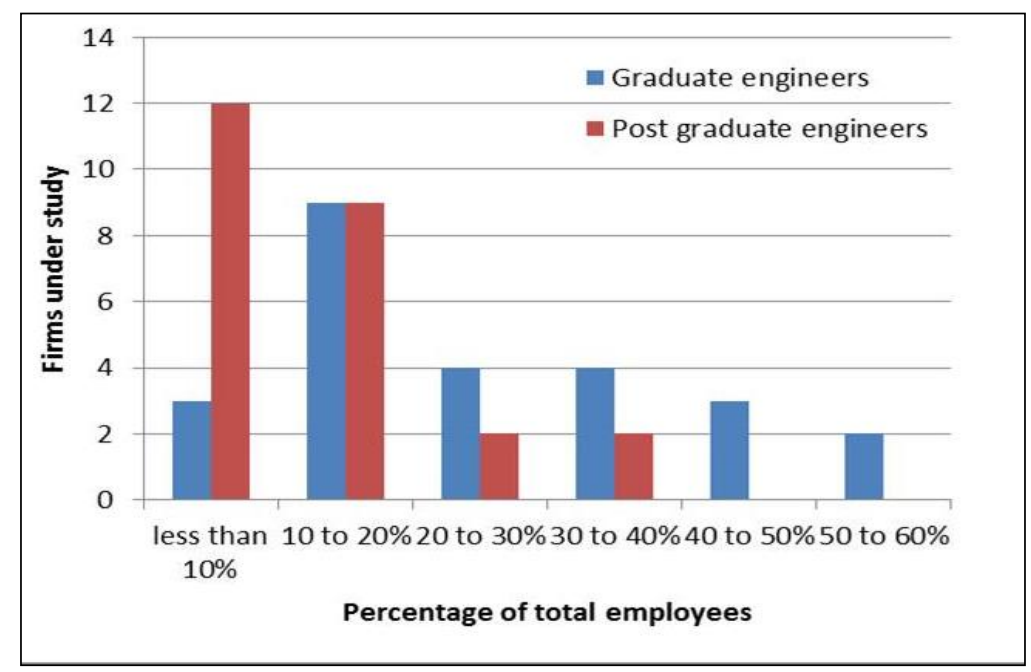

Fig. 4. Number of engineers employed by the firms

Further, contractors are mostly interested in cost savings and are not concerned much with the quality of works, hence short-term cost-saving measures are preferred in the local industry. However, there is still a consistent and substantial wastage of material in the local construction projects [33].

However, contractors follow the design recommendations for the construction material to avoid objections and associated work stoppages by the relevant organizations. Therefore, designers can influence the smart use of construction materials from strategies like the selection of reused or recycled materials where appropriate. Similarly, contractors can be incentivized to use recycled site waste and renewable materials to help reduce the quantity of site waste.

\subsubsection{Data archiving and knowledge management}

Another hurdle in uplifting the competitiveness of the local construction industry is that of data archiving and saving. The construction industry is a data-intensive industry where stakeholders exchange a lot of information throughout the different phases of the project lifecycle. However, the industry is unable to document, secure, and communicate this knowledge when required. Thus, important knowledge is constantly lost. According to the respondents, the local industry focuses greatly on storing explicit knowledge such as work breakdown structures, procedure manuals, organization structure, etc. But the tacit knowledge and lessons learned are rarely documented and stored, and made available to others or even to their own teams in helping to avoid common mistakes in the future. Thus, to achieve a competitive advantage, the industry should focus on capturing and reusing the tacit knowledge such as projectspecific knowledge and experience of the people. Some companies have documentation processes to record project knowledge like post-project reviews. But in most cases, they are not efficiently documented or stored for later use. Similarly, in some cases, knowledge management is limited to recording the site mishaps or failure events just to be casually discussed and no follow-up activities or status reports are carried out. Nevertheless, some respondents revealed that they have an intranet facility in their company, and employees are required to update their lessons learned database. Thus an instrument of record-keeping at the firm level is provided in some instances. Despite these scattered arrangements, the management of tacit knowledge is a major problem and the general perception is that knowledge management is the responsibility of top management instead of every individual, making it an issue with no assigned owner. As a result, records and knowledge management is compromised in the local industry. Further, there is a lack of issuing feedback on 
technical expertise from the client as highlighted by one respondent: "letter of recommendations is explicitly requested from the client, not given based on assessment". Such recommendations are mainly based on personal or business relations instead of the ground realities and are mostly falsified just to present a positive picture of organizations. Owing to these practices, the contractors are unable to selfassess and improve their operations. This creates hurdles in improving competitiveness.

\subsection{Investigation of the supporting factors}

\subsubsection{Industry-Academia collaboration}

One of the factors affecting competitiveness is the collaboration between the industry and academics. There is a lack of collaboration and interaction between academia and the industry in Pakistan as highlighted by Ullah and Thaheem [39]. Because of this weak connection, young engineers are not fully prepared and face deficiency of appropriate skills required for their jobs as underlined by the respondents. Moreover, the issue of brain drain cannot be neglected as local institutions are meeting the demands of engineers required by the industry but the qualified and expert people leave the country to pursue better professional and personal growth. But this limits the chances of innovation and entrepreneurial uplift of the local construction industry.

\subsubsection{Performance and proficiency of subcontractors}

Another factor affecting the competitiveness of the construction industry is the performance and proficiency of subcontractors since it drives firms and the industry. According to the respondents, subcontractors in the Pakistani construction industry are reliable and almost all the respondents expressed satisfaction over their skill and competence. Similarly, some firms have long associations with selected subcontractors who are groomed under their supervision and trained for the job. Others have strong selection processes that involve stringent background checks, past performance, industry goodwill, financial position, major projects, and technical expertise. However, in some cases, exceptions are made and personal relations came into play. In terms of the competition, there are several high-quality specialty subcontractors available locally, giving tough time to non-proficient subcontractors. However, there are some issues reported by a small number of respondents about the ignorance of technical issues, technical immaturity, negligence, or non-adherence to modern tools, and improper planning from the subcontractors mainly when procurement decisions are made on personal relations. But the respondents suggest that these issues can be addressed by establishing technical and vocational training centers for small enterprises to train them and uplift their skill set before entering the market.

\subsubsection{Innovation capabilities}

Another assessment factor for competitiveness is innovation. A majority of the interviewed organizations are aware of the concept of innovation and report using innovative techniques such as energy efficiency, cost-effectiveness, quality improvement, value engineering, etc. within the available resources and as per their requirement. However, these practices are not up to the mark that a comparison with the international market can be drawn as highlighted by the respondents since innovation requires new tools and plants which are not easily available in Pakistan. According to some respondents, they have taken a lead in the market due to efforts in exploring new methodologies and software, and convincing clients to implement these in their projects. Further, continuous efforts and investments in $\mathrm{R} \& \mathrm{D}$ are vital to providing a sound basis for enhancing and encouraging the adoption of innovative techniques. In this context, the government must apply a top-down approach by creating an independent body involving both public and private sector organizations and trying to bring foreign expertise, innovative practices, and investments in the local construction industry. Further, the absence of innovative practices can be linked to the dreadful education system and brain drain problems. Resultantly, Pakistan ranks at 110th position in the Global Competitiveness Index, 79th in Innovation Index, 105th in Brain 
Drain, and 107th in Quality of Education System [85], considerably lower than other regional players such as India, China, Malaysia, Indonesia, and Thailand. To balance the scale, there should be a parallel bottom-up approach where the domestic universities and research institutions should educate people to adopt new innovative practices and encourage more entrepreneurial practices. Positive steps are being taken in this context such as the introduction of student and entrepreneurial loans by national and local banks and the recently introduced Kamyab Jawan (Successful Youth) program by the Federal Government in 2019. However, their perks are yet to be seen in due time.

\subsection{Flexibility in approach and adoption of new tool}

\subsubsection{Adopting and using new and latest tools and} techniques

The local industry is flexible and absorbent enough to employ planning software like Primavera and MS Project by retiring the manual methods. But it struggles to implement cutting-edge technologies such as Building Information Modeling (BIM) to connect design and construction professionals at the same platform. Although steps are taken in this context through awareness seminars and trials and tests of BIM-based designs in some local firms, the full potential for local adoption is not sufficiently exhausted. Limited expertise, associated cost, lack of awareness, and the non-availability of supporting infrastructure are some of the main reported barriers to create a BIM environment $[38,86]$. Nevertheless, some organizations have realized its true capacity and are currently focusing on the implementation of BIM as the market demand is expected to intensify in the coming years especially with the customers and clients demanding 3D views and animations. This implementation is also a need of the hour since several Pakistani design consultancies exclusively cater to regional projects in the Middle East where BIM has become a mandatory requirement. As a result, such organizations run the risk of losing business. This is a strong driver for them to upgrade their skill set and as a result, a strong focus to implement BIM is witnessed in some organizations. But the contracting organizations have a lot of catching up to do.

\subsubsection{Health and safety initiatives}

Additionally, safety and quality culture are greatly discussed in the construction industry globally. In Pakistan, keeping aside the government instance on $\mathrm{H} \& \mathrm{~S}$ as discussed previously, some companies have started to roll the ball on safety and H\&S is receiving some attention. These steps include the provision of personal protective equipment (PPE) to workers and safety personnel to guide and implement safety within their capacity to prevent accidents. However, it is yet to transform and escalate into a national culture. Similarly, for the tools and techniques related to quality management of the local projects, there are mixed responses, as illustrated in Fig. 5.

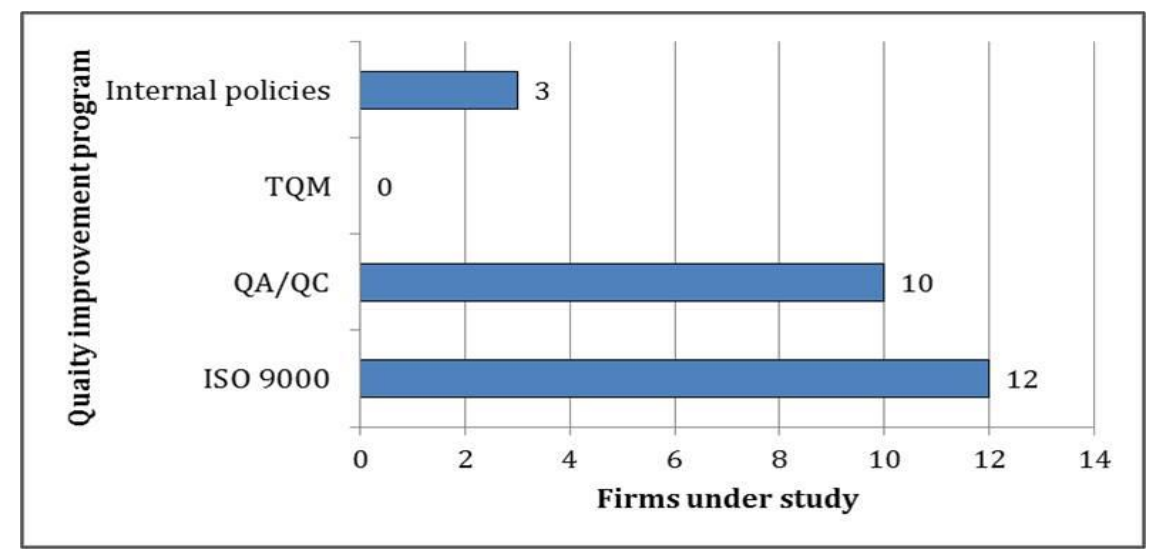

Fig. 5. Adoption of a quality control program 


\subsubsection{Quality management approaches}

Interestingly no interviewed organization is employing the Total Quality Management (TQM) for the quality control. It is mainly because of the involvement of all people, functions, and techniques of the firm in the TQM process, making it a complex task since the construction industry is faced with challenges of rigid stakeholder management. Resultantly, the interviewed organizations do not seem to have the capacity to manage such complexity. Additionally, most of the organizations seem to be satisfied with the ISO 9000 standards and are following it but only to the level of material procurement and lack a holistic quality management strategy. Similarly, more than half of the organizations reported having some sort of $\mathrm{QA} / \mathrm{QC}$ or internal quality control policy for ensuring quality. Additionally, the lack of training and quality of skilled workers is another issue as highlighted by the respondents. In the interviewed organizations, staff training is linked with the necessity and requirement of going along with the firm for which they have in-house training programs. But this is often restricted to the existing project sites and no such training is offered at the organizational level or outside the organization. In some cases, trained and qualified candidates are employed reducing their requirement for further training and cutting costs. Further, the provision of regular training programs offered by universities is minimally diffused since they are a part of the annual goals of the employees.

\subsection{The current potential}

According to Finance [83], during FY 2019, large scale manufacturing (LSM) GDP was around $13.5 \%$ in 2018 that has declined to $13.0 \%$ this year mainly due to the poor performance of major crops, power slippages, global commodity price shocks, and contraction in demand of the domestic consumption. LSM growth during July-March FY 2019 declined to $2.93 \%$ as compared to $6.33 \%$ in the same period last year. Further, on the year-onyear basis, LSM growth witnessed a sharp decline of $10.63 \%$ in March 2019 compared to an increase of $4.70 \%$ in March 2018. The most critical reason behind this shortfall is horrifyingly low labor productivity. A comparison of labor productivity among the regional contenders demonstrates that Pakistan has the least productive workforce and currently ranks lowest among the regional players. Low labor productivity together with financial constraints decreases the Total Factor Productivity (TFP). The issue of non-availability of skilled labor in Pakistan is due to the dearth of technical institutions responsible for producing trained workers and the brain drain issue where highly talented people are incentivized by developed countries to migrate and work for them. For the last eight years, the private sector has ventured into this sector such as the HUNAR foundation who are teaching basic skills and providing training to the local workforce. However, there is a severe need for more such technical organizations to train local labor. In this context, the establishment of the Technical Education \& Vocational Training Authority (TEVTA) and its affiliated institutes is a positive step by the government for producing skilled workers. However, due to its recent introduction, the state of practice is yet to benefit from these institutes and their graduates.

\subsection{Market for construction business}

As previously mentioned, despite meeting the demands of engineers required by the industry from local institutions, the domestic market is facing the problem of brain drain [87, 88]. Resultantly, the local market faces a shortage of skilled labor and entrepreneurial individuals, though it is quite rich in specialty subcontractors. Raw materials and finished products are readily available but there are issues and reservations related to the availability of advanced machinery in the local market. Despite all the variations in market conditions, the local industry is still surviving within the available resources. Additionally, some of the organizations are also expanding globally and are working successfully in global markets such as the Middle East [27].

Pakistan has risen to a rank of 108th in the world by climbing 28 places in the ease of doing business ranking this year from 136 the previous year [89]. 
But on the downside, Pakistan is yet to reinforce its domestic market and make a strong impact in the international markets mainly due to issues such as corruption (world rank 116) and inherent inefficiencies in the legal system. Thus, it ranks at 117 among 180 countries for transparency [90]. Globally, Pakistan stands at 105 th position among 189 economies on the ease of starting a business which is positive among regional players like India (179th) and China (158th) [89]. However, new firms face two major problems while entering the construction business in Pakistan: a small domestic market and a shaky business environment as stressed by Maqsoom and Charoenngam [27]. A key issue in conducting a successful construction business in Pakistan is that of the hardnosed clientsupplier relationship which requires trust-based arrangements. However, this relationship in the case of the construction projects in Pakistan is often conflicting rather than a win-win where both parties work together to achieve the holistic goals. Instead in the Pakistani construction industry, there seems to be a tug of war and denial of responsibility. However, on the positive side, contractors have the flexibility to select their suppliers from a vast supplier-base as well as the open market, minimizing the risk of high bargaining from the suppliers' end and carrying out the business on mutually agreed terms. Further, the local industry is benefiting from joint ventures in both design and contracting fields in international markets such as the Middle East and Africa. Joint ventures are preferred due to ease of establishing, knowledge of local laws, requirements of low resource commitments, and ease of risk-sharing. However, the lack of support from the government for expanding business in international markets remains the leading competitive disadvantage confronted by domestic firms [91].

\subsection{Economic and financial state to support the industry}

Pakistan's economy continues to confront challenges like energy crises, floods and rains, and law and order conditions that have held back the investment and growth in the country. Pakistan stood at 73rd position among 189 economies in 2013 on the ease of getting loans. But it has deteriorated in recent years leading to the refusal of loans and imposition of strict conditions on approval of such loans [92]. Large firms can easily obtain bank loans because of their long presence, credibility in the industry, creditworthiness, and personal links of the directors and managers. However, smaller and newer firms must count on their own financial resources or foreign banks to enter or remain in the business. Local banks do not facilitate these firms due to the saturated local market and ordinary macro-economic conditions as emphasized by Maqsoom and Charoenngam [27]. This creates a major project financing crisis due to heavy reliance on equities.

Private investment in Pakistan is observing a decline in recent years. According to Bank [89], Pakistan is not investing enough and its share of investment to GDP is one of the lowest in the world at $15 \%$. Further, private investment has declined and stands at less than $10 \%$ as of 2018. Currently, both domestic and foreign investments are inadequate due to adverse investment climate, indicated by idle capacities, security concerns, energy shortages, low public investments, and unfocused trade. To rectify these, Pakistan needs to take action and increase public investment in key infrastructure and human capital. Similarly, improving the business environment is a must to tap into foreign resources.

\subsection{Competitiveness assessment through fuzzy analysis}

As previously explained, all the interview respondents were requested to rate the competitiveness of the construction industry of Pakistan on a scale ranging from 'extremely low' to 'extremely high'. Once the responses were received, a fuzzy analysis was run. The result, as shown in Fig. 6, place the Pakistani construction sector in the "fairly high" region in terms of its competitiveness. This is mainly due to the recent introductions of the incentives and a training culture in the construction industry of Pakistan as highlighted by the respondents. 


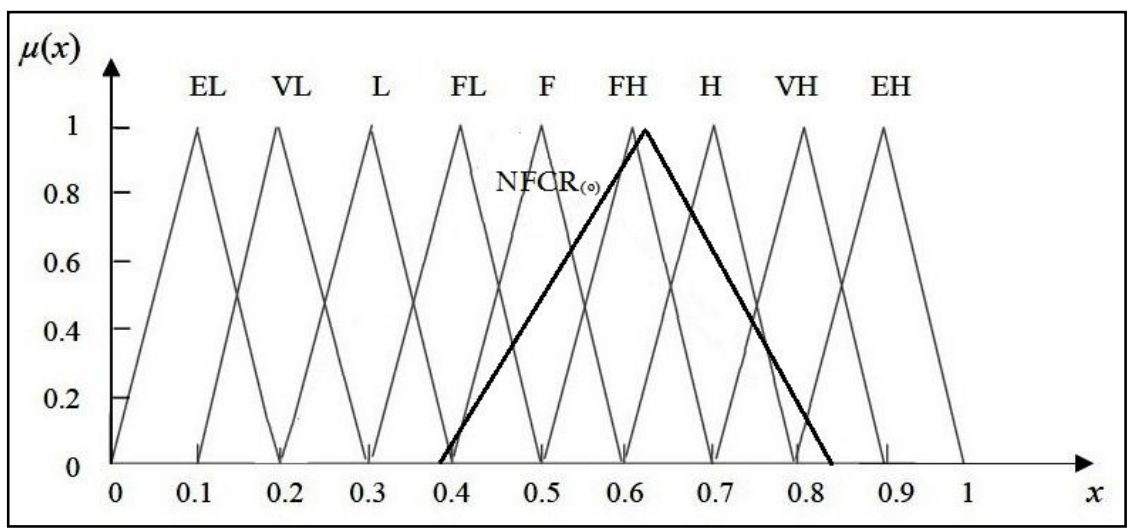

Fig. 6. Match NFCR $(\mathrm{O})$ to the natural language expression set

Further, organizations such as PEC and the Ministry of Workforce and Labor are devising rules and regulations for compliance with the construction industry. Similarly, TEVTA and other training institutes are introduced for developing a skilled workforce, raising the standards of the industry. However, in terms of innovation, entrepreneurship, and global competitiveness, the industry has a long way to go and needs to learn from the experience of developed or rapidly developing countries. The local construction industry must be incentivized through tax rebates, concessions, and award systems to drive investment in $R \& D$ and the use of renewable and sustainable materials. Further, legislation must be done and implemented across the industry to ensure safe working, H\&S, waste reduction, and improved quality of works. The result of the fuzzy analysis of the seven criteria of competitiveness focused in this study is shown in Fig. 7.

Accordingly, the overall competitiveness of the Pakistani construction industry is fairly high with some domains such as finances and economics, the present potential, supporting factors, and firm-level competitiveness getting scores near to high region. This shows the potential for growth and rising awareness among the key stakeholders of the construction industry of Pakistan. However, on the downside, the overall environment of the construction industry and its flexibility towards innovation and adoption of updated technologies is somewhere between the fair and fairly high range. Thus, it is underperforming compared to other aspects. The industry needs to raise its state of the adoptive environment and be more flexible allowing for entrepreneurial ventures and adoption of innovative tools and techniques if it is to compete in the rapidly changing global world.

\section{Conclusions and recommendations}

The state of the Pakistani construction industry is mixed with some positive aspects such as the absorption of technology and skilled workforce. The industry has the potential to break the ice by making significant efforts to embrace ICT solutions. Further, some government policies are being formulated that if properly followed will support the industry to become more competitive. However, there are serious issues that need immediate attention such as H\&S-related legislation, environmental regulations, investment in $\mathrm{R} \& \mathrm{D}$, and support for expanding business in international markets. In the absence of a holistic plan and framework for enhancing the competitiveness of the local construction industry and drafting provisions for adoption, the situation will only deteriorate. In this context, it is necessary to recognize and subsequently plan for crucial factors for enhancing the construction competitiveness. These include strategic planning, as the industry seems not to grasp its concept. Further, the recruitment of well-trained and qualified human resource and cutting-edge technologies and the sustainability measures, not just to optimize cost but also natural resources, need to be focused. 


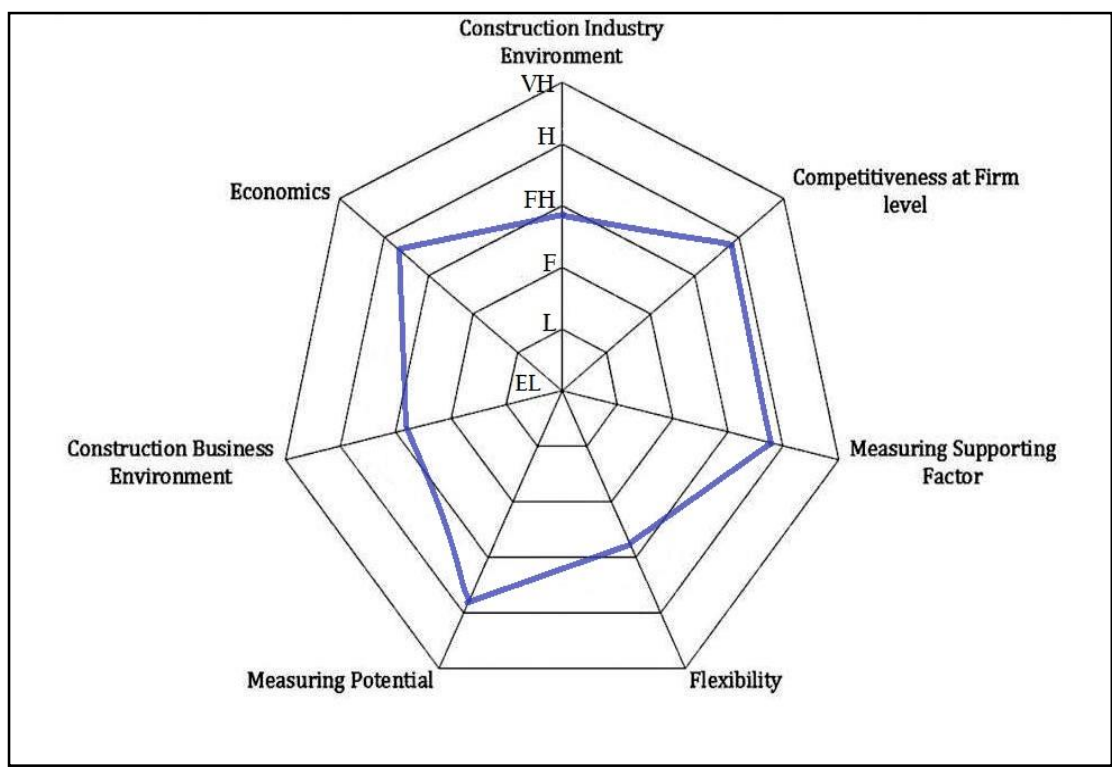

Fig. 7. Competitiveness level of seven selected parameters

Additionally, focus on the capture and reuse of tacit knowledge along with explicit knowledge, serious investment in training and development of staff, and trust-based client-supplier relationships are essential for uplifting the state of the local construction industry

The domestic market boasts enough suppliers and quality subcontractors. However, the least productive and scarcely available skilled labor, brain drain, rarely available advanced equipment and machinery are some of the highlighted issues that hinder the process of adopting innovation and becoming competitive. Further, security concerns, energy shortages, and unfocused trade policies are other key hurdles in the growth of domestic as well as foreign investment. Attaining competitiveness will certainly require the participation of not only the construction organizations, but also of the academia, active performers from material suppliers to customers, and the government to develop a holistic approach. Owing to these, a development model as shown in Fig. 8 is proposed that encapsulates the policy framework aimed at achieving a highly competitive construction industry of Pakistan.

The proposed framework, based on the data collected and perception of experienced respondents working in managerial positions in the interviewed contractor organizations, outlines the key steps to attain a more sustainable, smarter, innovative, and competitive construction industry in Pakistan. According to the proposed framework, a five-pronged approach must be adopted based on the domestic market requirements for attaining the goals of the competitive construction industry. These include outlining the responsibilities of the government concisely through nationwide available, accepted, and enforced rules of engagement in the construction business along with the expectations from the contractors and other construction firms. This will ensure that the responsibilities are divided, and risk is shared in a balanced way, giving a sense of security to the organizations about value for their money and attracting more investment. Similarly, the second step involves the development of environmentfriendly solutions where the organizations are motivated and incentivized to invest in $R \& D$ and green material. Using such environment-friendly material, waste reduction and recycling can be achieved. Awards and tax rebates for using green, environment-friendly, and sustainable materials can amplify competitiveness. Another very important step is the collaboration between academia and industry. 


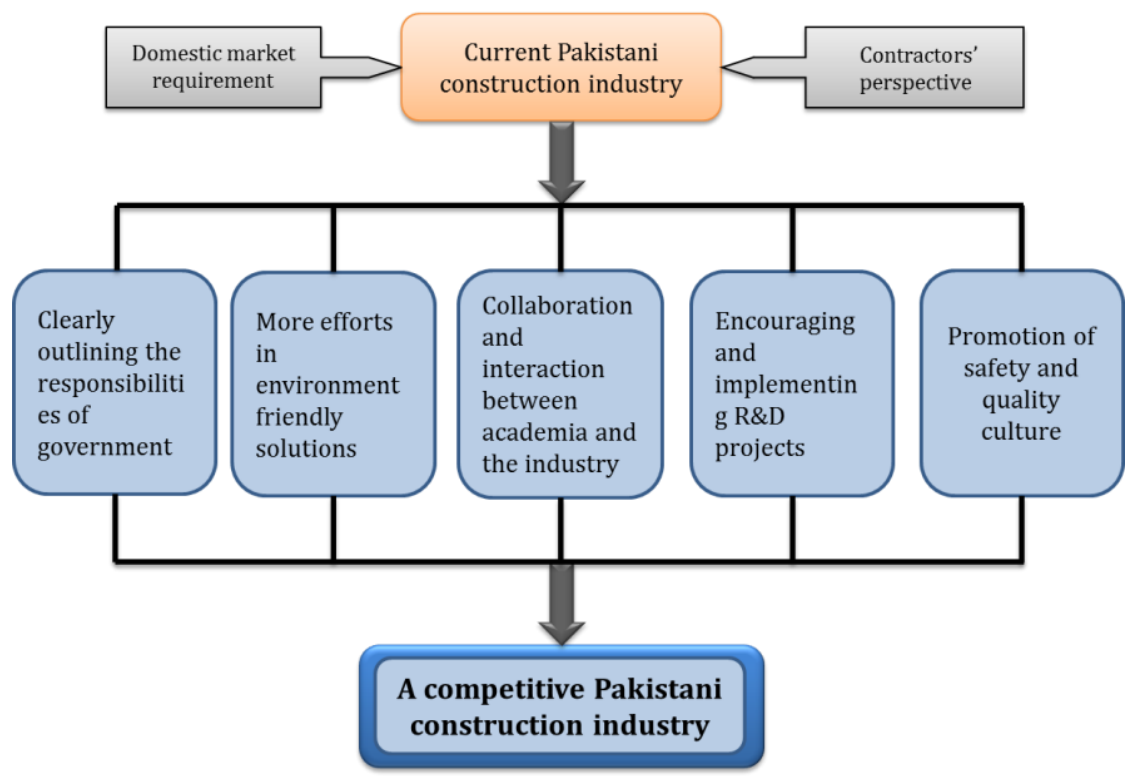

Fig. 8. Development model for a competitive construction industry

These two significant players can act as a lifeline to each other and help one another thrive through collaborations and research. Academia can learn from industrial experience and in return share the research experience and findings with the industry. A collaborative environment can provide testing grounds for novel research and innovative materials that can help uplift the state of the industry. The next step involves investments in $\mathrm{R} \& \mathrm{D}$ projects by both public and private organizations for developing and subsequently using energy-efficient designs, smarter and green materials, and innovative means of cost reduction and quality improvement. Such R\&D ventures can be started by the government and the private sector can be incentivized to collaborate with them or even start their own R\&D ventures and help uplift the state of practice. Lastly, $H \& S$ and quality management practices need a lot of effort and attention. In this context, the legislation must be done and a dedicated implementation body must be formed on priority. Additionally, awareness seminars, translation of signs in the local language, providing and enforcing the use of PPE, and concepts of demerits for noncompliance of safety rules can be helpful in this context. Similarly, for quality management, new tools and techniques such as TQM, Six Sigma, and lean construction can be adopted as suggested by Ullah, Thaheem [30] and Hussain, He [93].

The current study investigates the state of competitiveness of the Pakistani construction industry from a contractor's perspective and is limited in its approach since it does not incorporate the opinions of other key stakeholders. The future works can extend this study by incorporating the opinions from other key stakeholders such as consultants, government officials, and private financers. Additionally, the availability of local data and lack of research in the local context are other limiting factors confining the results of the current study. Further, this study has implications for both research and practice. In terms of research, it explores areas and aspects of competitiveness of the local construction industry that were not investigated before and at the same time, it opens avenues for debate and research across the board to uplift the current state of practice in the Pakistani construction industry. In terms of the practical implication, the study provides policy guidelines in the form of a development framework that can help the construction industry adopt innovation and move forward to become a competitive and modern 
industry that can attract huge investment and play its role in the development of the country.

\section{Ethics committee permit and/or legal/special permission}

The authors confirm that no ethics committee permit is necessary for this type of data collection in Pakistan. However, special permissions have been obtained from the respondents to participate in the study and getting their responses published without revealing their identities.

\section{Declaration of conflicting interests}

The author(s) declare no potential conflicts of interest for the research, authorship, and/or publication of this article

\section{Acknowledgments}

The authors acknowledge the employees of various construction companies for their valuable input enabling us to complete this research, for which no funding was provided by any academic institute or industry.

\section{References}

[1] Henricsson J, Ericsson S, Flanagan R, Jewell C, Rethinking competitiveness for the construction industry. Proceedings of the 20th Annual ARCOM Conference, 9 September 2004, Heriot Watt University, Edinburgh, Scotland.

[2] Ozorhon B, Kus C, Caglayan S (2020) Assessing competitiveness of international contracting firms from the managerial perspective by using Analytic Network Process. Journal of Construction Engineering, Management \& Innovation 3(1): 5266.

[3] Sabug BJR, Pheng LS (2018) Competitive and entry strategies for UK transnational contractors in the Singapore rail sector. International Journal of Construction Management 20(7): 1-24.

[4] Badawy A. An Evaluation Model for Competitiveness Index of Construction Companies. MSc Thesis, Concordia University, 2018.

[5] Rodionov D, Kichigin Oleg E, Selentieva Tamara N (2019) Features of assessing the competitiveness of innovative regional clusters: an institutional approach. St Petersburg State Polytechnical University Journal Economics 75(1): 43-58.

[6] Safonova O, Tatarnikova L. Assessment of the competitiveness of industrial companies and methods for assessing the quality of construction products. E3S Web of Conferences, Topical Problems of Green Architecture, Civil and Environmental Engineering 2019 (TPACEE 2019), 05 May 2020.

[7] Ullah F, Thaheem MJ, Sepasgozar SM, Forcada N (2018) System dynamics model to determine concession period of PPP infrastructure projects: overarching effects of critical success factors. Journal of Legal Affairs and Dispute Resolution in Engineering and Construction 10(4):04518022.

[8] Ullah F. Estimating concession period for public private partnership (PPP)-based infrastructure development: Application of LCCA for highway projects. MSc Thesis, National University of Sciences and Technology, 2015.

[9] Mehmood Y, Zahoor H, Ullah F (2019) Economic efficiency analysis of rawalpindi bypass project: a case study. Innovative Production and Construction-Transforming Construction through Emerging Technologies, Chapter: 30, World Scientific, pp 531-541.

[10] Fox P, Skitmore M (2002) Key factors in the future development of the construction industry. Proceedings of the 1st CIB-W107 International Conference - Creating a Sustainable Construction Industry in Developing Countries, CSIR, 2002, Pretoria, South Africa.

[11] Low WW, Abdul-Rahman H, Zakaria N (2020) Organisational culture of Malaysian international construction organisations. International Journal of Construction Management 20(2): 105-21.

[12] Shabbar H, Ullah F, Ayub B, Thaheem MJ, Gabriel HF (2017) Empirical evidence of extension of time in construction projects. Journal of Legal Affairs and Dispute Resolution in Engineering and Construction 9(3): 04517008.

[13] Bettemir Ö, Erzurum T (2019) Comparison of resource distribution metrics on multi-resource projects. Journal of Construction Engineering, Management \& Innovation 2(2): 93-102.

[14] Siddiqui SQ, Ullah F, Thaheem MJ, Gabriel HF (2016) Six Sigma in construction: a review of critical success factors. International Journal of Lean Six Sigma 7(2): 171-86.

[15] Ullah F, Ayub B, Siddiqui SQ, Thaheem MJ (2016) A review of public-private partnership: critical 
factors of concession period. Journal of Financial Management of Property and Construction 21(3): 269-300.

[16] Sheikh NA, Ullah F, Ayub B, Thaheem MJ (2017) Labor productivity assessment using activity analysis on semi high-rise building projects in Pakistan. Engineering Journal 21(4): 273-86.

[17] Hamza M, Shahid S, Bin Hainin MR, Nashwan MS (2019) Construction labour productivity: review of factors identified. International Journal of Construction Management 15(4): 1-13.

[18] Irfan M, Zahoor H, Abbas M, Ali Y (2020) Determinants of labor productivity for building projects in Pakistan. Journal of Construction Engineering, Management \& Innovation 3(2): 85100.

[19] Jaafar M, Nuruddin AR, Bakar SPSA (2016) Managerial capabilities of housing developers: Building the competitive advantage of a firm. International Journal of Construction Management 16(1): 27-38.

[20] Abbas S, Waheed A (2017) Trade competitiveness of Pakistan: evidence from the revealed comparative advantage approach. Competitiveness Review: An International Business Journal 27(5): 462-75.

[21] Shahzad K, Arenius PM, Huq A, Elkins M. The Effect of Common Facility Centre (CFC) Program on SMEs' Competitiveness in Pakistan. Academy of Management Proceedings; 2019: Academy of Management Briarcliff Manor, NY 10510.

[22] Lateef M, Guang-ji T, Riaz MU, Ishaq MN, Abdullah M, Ahmad Z (2018) Agricultural Exports Competitiveness of Pakistan in Global Market. Journal of Northeast Agricultural University (English Edition) 25(2):77-87.

[23] Abdullah M, Li J, Ghazanfar S, Ahmed J, Khan I, Ishaq MN (2015) Where Pakistan stands among top rice exporting countries, an analysis of competitiveness. Journal of Northeast Agricultural University (English Edition) 22(2): 80-6.

[24] Siddiq A. Strategic Leadership's Competitiveness in Healthcare System of Pakistan. PhD Thesis Islamia Collage Peshawar, 2019.

[25] Qadir U. Technology Acquisition, Catching Up and Competitiveness in Pakistan. Pakistan Institute of Development Economics, 2016.

[26] Martin R, Kitson M, Tyler P. Regional competitiveness. Routledge, 2012.

[27] Maqsoom A, Charoenngam C (2014) Motives and competitive assets of Pakistani international construction contracting firms: Impact of size and international experience. Journal of Financial Management of Property and Construction 19(2): 138-51.

[28] Ullah F, Thaheem M, Umar M. Public-private partnerships in Pakistan: A nascent evolution. Cambridge Scholars Newcastle upon Tyne, UK; 2017.

[29] Ayub B, Thaheem MJ, Ullah F (2019) Contingency release during project execution: The contractor's Decision-making dilemma. Project Management Journal, 50(6): 734-748.

[30] Ullah F, Thaheem MJ, Siddiqui SQ, Khurshid MB (2017) Influence of six sigma on project success in construction industry of Pakistan. The TQM Journal 29(2): 276-309.

[31] Hasnain M, Thaheem MJ, Ullah F (2018) Best value contractor selection in road construction projects: ANP-based decision support system. International Journal of Civil Engineering 16(6): 695-714.

[32] Kamal A, Zahoor H, Ali B, Babar S, Maqsoom A (2019) Influence of risk factors on project's objectives in construction industry of Pakistan. Journal of Construction Engineering and Management.

[33] Arshad H, Qasim M, Thaheem MJ, Gabriel HF (2017) Quantification of material wastage in construction industry of Pakistan: An analytical relationship between building types and waste generation. Journal of Construction in Developing Countries 22(2): 19-34.

[34] Maqsoom A, Khan MU, Khan MT, Khan S, Ullah F. Factors influencing the construction time and cost overrun in projects: empirical evidence from Pakistani construction industry. Proceedings of the 21st International Symposium on Advancement of Construction Management and Real Estate, Springer, 2018.

[35] Ayub B, Ullah F, Rasheed F, Sepasgozar SM. Risks in EPC hydropower projects: A case of Pakistan. 8th International Civil Engineering Congress (ICEC) Ensuring Technological Advancement through Innovation Based Knowledge Corridor, 23-24 December 2016, Karachi, Pakistan.

[36] Jokar E, Aminnejad B, Lorak A (2020) Risk prioritization and selection of contractor participating in Public-Private Partnership (PPP) infrastructure project using Hybrid Fuzzy AHP and Fuzzy TOPSIS (Case Study: Saveh-Salafchegan Freeway Project). Journal of Construction 
Engineering, Management \& Innovation 3(1): 116.

[37] Ahmad Z, Thaheem MJ, Maqsoom A (2018) Building information modeling as a risk transformer: An evolutionary insight into the project uncertainty. Automation in Construction 92: 103-19.

[38] Ali B, Zahoor H, Mazher KM, Maqsoom A. BIM implementation in public sector of Pakistan construction industry. ICCREM 2018: Innovative Technology and Intelligent Construction: American Society of Civil Engineers Reston, VA, 2018.

[39] Ullah F, Thaheem MJ (2018) Concession period of public private partnership projects: industryacademia gap analysis. International Journal of Construction Management 18(5): 418-29.

[40] Cao D, Li H, Wang G, Luo X, Tan D (2018) Relationship network structure and organizational competitiveness: Evidence from BIM implementation practices in the construction industry. Journal of management in engineering 34(3): 04018005.

[41] Lu W, Shen L, Yam MC (2008) Critical success factors for competitiveness of contractors: China study. Journal of construction engineering and management 134(12): 972-82.

[42] Toppinen A, Sauru M, Pätäri S, Lähtinen K, Tuppura A (2019) Internal and external factors of competitiveness shaping the future of wooden multistory construction in Finland and Sweden. Construction Management and Economics 37(4): 201-16.

[43] Hong S W C. Competitiveness in the tourism sector: A comprehensive approach from Economic and Management points. Springer Science \& Business Media, 2008.

[44] Orozco F A, Serpell AF, Molenaar KR, Forcael E (2011) Modeling competitiveness factors and indexes for construction companies: Findings of Chile. Journal of Construction Engineering and Management 140(4): B4013002.

[45] Lin C, Xu X, Du S (2019) Analysis and evaluation of international competitiveness of China's stateowned technology enterprises in marine industry. Journal of Coastal Research 94(sp1): 687-91.

[46] Malmberg A, Maskell P. Localised capabilities and industrial competitiveness. Voices from the North: Routledge, pp 11-28, 2018.

[47] Chang R D, Zuo J, Zhao Z Y, Soebarto V, Lu Y, Zillante G, Gan X L (2018) Sustainability attitude and performance of construction enterprises: A China study. Journal of Cleaner Production 172: 1440-51.

[48] Camagni R. Regional competitiveness: towards a concept of territorial capital. Seminal Studies in Regional and Urban Economics, Springer, pp 11531, 2017.

[49] Aldy JE, Pizer WA (2015) The competitiveness impacts of climate change mitigation policies. Journal of the Association of Environmental and Resource Economists 2(4): 565-95.

[50] Cahlikova J, Cingl L, Levely I (2020) How stress affects performance and competitiveness across gender. Management Science 66(8): 3295-3310.

[51] Xia H, Vu HQ, Law R, Li G (2020) Evaluation of hotel brand competitiveness based on hotel features ratings. International Journal of Hospitality Management 86: 102366.

[52] Flanagan R, Lu W, Shen L, Jewell C (2007) Competitiveness in construction: a critical review of research. Construction Management and Economics 25(9): 989-1000.

[53] Orlov A, Chubarkina I. Implementation of construction projects for social infrastructure development in Smart Cities. IOP Conference Series: Materials Science and Engineering, IOP Publishing, 2018.

[54] Ullah F, Samad Sepasgozar P, Ali T H. Real Estate Stakeholders Technology Acceptance Model (RESTAM): User-focused Big9 disruptive technologies for smart real estate management. International Conference on Sustainable Development in Civil Engineering, MUET, 05-07 December 2019, Pakistan.

[55] Ullah F, Sepasgozar S M E (2019) A study of information technology adoption for real-estate management: A system dynamic model. Innovative Production and Construction: Transforming Construction Through Emerging Technologies 469-486.

[56] Ullah F, Sepasgozar S M, Wang C (2018) A systematic review of smart real estate technology: Drivers of, and barriers to, the use of digital disruptive technologies and online platforms. Sustainability 10(9): 3142 .

[57] Ullah F, Sepasgozar S M (2020) Key factors influencing purchase or rent decisions in smart real estate investments: A system dynamics approach using online forum thread data. Sustainability 12(11): 4382. 
[58] Low S, Ullah F, Shirowzhan S, Sepasgozar S M, Lee C L (2020) Smart digital marketing capabilities for sustainable property development: A case of Malaysia. Sustainability 12(13): 5402.

[59] Pan W (2018) Rethinking construction productivity theory and practice. Built Environment Project and Asset Management 8(3): 234-8.

[60] Flanagan R, Ericsson C, Stefan Henricsson P (2005) Measuring construction competitiveness in selected countries. UK: Univ of Reading.

[61] Sutrisna M, Pellicer E, Torres-Machi C, Picornell M (2020) Exploring earned value management in the Spanish construction industry as a pathway to competitive advantage. International Journal of Construction Management 20(1): 1-12.

[62] Pan W, Chen L, Zhan W (2018) PESTEL analysis of construction productivity enhancement strategies: A case study of three economies. Journal of Management in Engineering 35(1): 05018013.

[63] Engel L C, Siczek M M (2018) A cross-national comparison of international strategies: global citizenship and the advancement of national competitiveness. Compare: A Journal of Comparative and International Education 48(5): 749-67.

[64] Scott B R, Lodge G C (1985) US competitiveness in the world economy. The International Executive 27(1): 26-26.

[65] Yari M, Duncan R (2007) Competitiveness: An essential ingredient for growth in Asian and Pacific developing countries in a globalizing world. AsiaPacific Development Journal 14(1): 125.

[66] Bayhan H, Polat G (2019) Green certified shopping malls undertaken by foreign contractors in Russia: A comparative qualitative study. Journal of Construction Engineering, Management \& Innovation 2(2): 67-81.

[67] Feurer R, Chaharbaghi K (1994) Defining competitiveness: a holistic approach. Management Decision 32(2): 49-58.

[68] Swab R G, Johnson P D (2019) Steel sharpens steel: A review of multilevel competition and competitiveness in organizations. Journal of Organizational Behavior 40(2): 147-65.

[69] Bloodgood J M (2019) Knowledge acquisition and firm competitiveness: The role of complements and knowledge source. Journal of Knowledge Management 23(1): 46-66.

[70] Ivancevich J M, Lorenzi P, Skinner S J. Management: Quality and competitiveness. McGraw-Hill/Irwin, 1997.
[71] Porter M E (1979) How competitive forces shape strategy. Harvard Business Review 57(2): 137-45.

[72] Porter M E (1990) The Competitive Advonioge of Notions. Harvard business review.

[73] Lall S (2001) Competitiveness indices and developing countries: An economic evaluation of the global competitiveness report. World development 29(9): 1501-25.

[74] Chung T W (2016) A study on logistics cluster competitiveness among Asia main countries using the Porter's diamond model. The Asian Journal of Shipping and Logistics 32(4): 257-64.

[75] Koc K, Gurgun A P (2020) Drivers for construction stakeholders to adopt smart contracts. Journal of Construction Engineering, Management \& Innovation 3(2): 101-12.

[76] Baker S E, Edwards R, Doidge M (2018) How many qualitative interviews is enough?: Expert voices and early career reflections on sampling and cases in qualitative research. National Centre for Research Methods Review Paper, Journal of Law and Society 27: 273.

[77] Boddy C R (2016) Sample size for qualitative research. Qualitative Market Research: An International Journal 19(4): 426-32.

[78] Fugard A J, Potts H W (2015) Supporting thinking on sample sizes for thematic analyses: a quantitative tool. International Journal of Social Research Methodology 18(6): 669-84.

[79] Öz Ö (2001) Sources of competitive advantage of Turkish construction companies in international markets. Construction Management and Economics 19(2): 135-44.

[80] Gabriel A S, Campbell J T, Djurdjevic E, Johnson RE, Rosen CC (2018) Fuzzy profiles: Comparing and contrasting latent profile analysis and fuzzy set qualitative comparative analysis for personcentered research. Organizational Research Methods 21(4): 877-904.

[81] Maqsoom A, Rehman J U, Umer M, Thaheem M J, Khan M J, Nawaz A, Najem M, Nazir T (2020) Exploring managerial perspectives of using building management system through TAM: An empirical study of commercial sector of Pakistan. Periodica Polytechnica Civil Engineering 64(3).

[82] Maqsoom A, Wazir S J, Choudhry R M, Thaheem M J, Zahoor H (2020) Influence of perceived fairness on contractors' potential to dispute: Moderating effect of engineering ethics. Journal of Construction Engineering and Management 146(1): 04019090. 
[83] Finance Mo. Pakistan Economic Survey 2018-19 Islamabad Pakistan: Government of Pakistan; 2019 [Available from: http://www.finance.gov.pk/survey/chapters_19/Ec onomic_Survey_2018_19.pdf.

[84] Munawar H S, Qayyum S, Ullah F, Sepasgozar S (2020) Big data and its applications in smart real estate and the disaster management life cycle: A systematic analysis. Big Data and Cognitive Computing 4(2): 4

[85] Schwab K. The Global Competitiveness Report 2019: World Economic Forum, 2019 [Available from:

http://www3.weforum.org/docs/WEF_TheGlobal CompetitivenessReport2019.pdf.

[86] Abbas A, Din Z U, Farooqui R (2016) Integration of BIM in construction management education: an overview of Pakistani Engineering universities. Procedia Engineering 145: 151-7.

[87] Laila S U, Fiaz M F (2018) Impact of brain drain on economic growth in Pakistan. The Business \& Management Review 9(4): 548-52.

[88] Sajjad N (2011) Causes and solutions to intellectual brain drain in Pakistan. Dialogue 6(1): 31-55.

[89] Bank T W. The World Bank in Pakistan: The World Bank; 2019 [Available from: https://www.worldbank.org/en/country/pakistan/o verview.

[90] International T. Transparency InternationalPakistan: Transparency International. 2019 [Available from: https://www.transparency.org/country/PAK.

[91] Razzaq A, Thaheem M J, Maqsoom A, Gabriel H F (2018) Critical external risks in international joint ventures for construction industry in Pakistan. International Journal of Civil Engineering 16(2): 189-205.

[92] Bank T W. The World Bank in Pakistan: The World Bank; 2013 [Available from: https://www.worldbank.org/en/country/pakistan/o verview.

[93] Hussain K, He Z, Ahmad N, Iqbal M (2019) Green, lean, Six Sigma barriers at a glance: A case from the construction sector of Pakistan. Building and Environment 106225.

[94] Ergin S, Ergina E, Sidorenko IY, Shamileva E. Problematic aspects of the development of a competitive environment in the production of construction materials in the Crimea. IOP Conference Series: Materials Science and Engineering, IOP Publishing, 2019.
[95] Pries F, Janszen F (1995) Innovation in the construction industry: the dominant role of the environment. Construction Management and Economics 13(1): 43-51.

[96] Du J, Chen Z (2018) Applying organizational ambidexterity in strategic management under a "VUCA" environment: Evidence from high tech companies in China. International Journal of Innovation Studies 2(1): 42-52.

[97] Falciola J, Jansen M, Rollo V (2020) Defining firm competitiveness: A multidimensional framework. World Development 129: 104857.

[98] Mohamad M R, Zin N M (2019) Knowledge management and the competitiveness of small construction firms. Competitiveness Review an International Business Journal 29(5): 534-550.

[99] Lapidus A, Abramov I. Studying the methods for determining and maintaining sustainability of a construction firm. MATEC Web of Conferences, EDP Sciences, 2018.

[100] Altun M, Sonmez R, Akcamete A (2020) A mixed integer programming method for multi-project resource leveling. Journal of Construction Engineering, Management \& Innovation 3(2): 13140.

[101] Chang R D, Soebarto V, Zhao Z Y, Zillante G (2016) Facilitating the transition to sustainable construction: China's policies. Journal of Cleaner Production 131: 534-44.

[102] Zhang J, Guan J (2018) The time-varying impacts of government incentives on innovation. Technological Forecasting and Social Change 135: 132-44.

[103] Lim B T, Ling F Y, Ibbs C W, Raphael B, Ofori G (2011) Empirical analysis of the determinants of organizational flexibility in the construction business. Journal of Construction Engineering and Management 137(3): 225-37.

[104] Song H, Zhu F, Klakegg O J, Wang P (2018) Relationship between contractual flexibility and contractor's cooperative behavior. International Journal of Managing Projects in Business.

[105] Xue X, Shen Q, Ren Z (2010) Critical review of collaborative working in construction projects: Business environment and human behaviors. Journal of Management in Engineering 26(4): 196208.

[106] Oyewobi L O, Windapo A, Rotimi J O B, Jimoh R (2020) Analysis of the South African construction industry business environment. Journal of Facilities Management 1472-5967. 
[107] Bilal M, Khan K I A, Thaheem M J, Nasir A R (2020) Current state and barriers to the circular economy in the building sector: Towards a mitigation framework. Journal of Cleaner Production 123250.

[108] Ullah F, Ayub B, Siddiqui S Q, Thaheem M J (2016) A review of public-private partnership: Critical factors of concession period. Journal of Financial Management of Property and Construction.

[109] Khan R A. Role of construction sector in economic growth: Empirical evidence from Pakistan economy. Proceedings of the First International Conference on Construction in Developing Countries (ICCIDC), 2008, Karachi, Pakistan. 